\title{
Collaborative Planning in Policy-Making Process in Bandung City
}

\author{
Antik Bintari ${ }^{1 \mathrm{a}}$; Idil Akbar ${ }^{1}$ \\ ${ }^{1}$ Government Science Department, University of Padjadjaran, Bandung, Indonesia \\ ${ }^{a}$ Corresponding author: antikisw@gmail.com
}

\begin{abstract}
Collaborative planning is the process of decision making where all stakeholders involved and construct a solution to solve problems together and formulated in an agreement. The city of Bandung has been implementing this collaborative planning, one of these is the innovative program for development and empowerment territoriality (Program Inovasi Pembangunan dan Pemberdayaan Kewilayahan -- PIPPK). In this program, Bandung city government gives freedom on every member of society who was coordinated by Rukun Warga (RW) for planning various types of development activities in the region to then pour in the proposals submitted by the Government to the city of Bandung for funded. This article aims to provide a clearer picture of how collaborative planning progress in the community and able to provide the benefits in the development in the city of Bandung. Research was done using qualitative methods analytically, with deep and comprehensive analysis of the object that is examined and perform analysis of the facts. Data collected by observation, in-depth interviews and literature study. Collaborative planning gives a great opportunity in the community to formulate the plan activities and development in the territory of each. The involvement of the society in collaborative planning is done directly from the formulation until evaluation. So that that way the community feels have what they had planned together.
\end{abstract}

Keywords-collaborative planning, bandung city, PIPPK, policy-making process

\section{INTRODUCTION}

In the perspective of old public administration, the government dominated the formulation and implementation of public policy. Service provider in the community is done through public agencies. Public organizations effectively done in a closed system and limited for citizens to involved more [1]. While in the new paradigm of public governance, emphasis more on how public policy and public service will be carried out using a new paradigm of public service that describes a policy implementation and public service-oriented service public oriented [2].

Paradigm change is more or less also influenced by gains in democratic governance, which requires a transformation in the process of public policy. For the reality show that the process of public policy more days requires the involvement of non-state actors outside of the broader country. The demands for the quality of the policy that the higher also made us aware that the process of public policy should involve the non-state actors in the wider outside the existing actors in the legislative and executive because they might have information, experience, and tacid knowledge is better than non-state actors that have a valid authority.

How far deliberative policy are able to work and implemented by the concrete by local government? Whether there will together (MGMP) in the process of formulating public policy that done? These questions are essentially based on the fact that the tendency of a public policy formulated and carried out partially, little done through - what is termed Healey as - collaborative planning [3].

Collaborative planning is the process of decision making where various stakeholders who see problems from different angles, sitting together to explore their differences to constructively, then seek solutions and to get more from what is obtained if only to find their own solutions. Collaborative planning is based planning communication (rationality communicative). In other words, collaborative planning is planning that oriented on the stakeholders and involve the various stakeholders.

This research done in Bandung with the consideration that the city of Bandung has several important example (best practice) how in the formulation of its policies, they have been able to apply what is called as a deliberative public policy through planning a collaborative. One example is the regional policy in the form of PIPPK. Through the program, the city government of Bandung billed funds disbursed Rp 100 million for each RW. Through this program, Bandung citizens who have planned activities related to the hygiene, order, beauty or plan to buy the instruments of the cleanliness and etc. will be prioritized.

Interestingly, all activities from the formulation, implementation to completion finally done by the community. Then the community will submit a proposal submission to the Government of the city of Bandung. The Mayor of Bandung, Ridwan Kamil said his system intensive, done itself by the citizens. The workmen, supervisor, contractors, hot plugging organizer, all by the host so that the citizens of work, citizen benefit of workmanship, was the concept [4].

Based on the above background, interesting study further how actually the Government of the city of Bandung build and formulate policies deliberatively, by involving citizens 
especially in making collaborative planning region and the society.

\section{RESEARCH METHOD}

The research using qualitative approach to produce an indepth explanation about the words, writing and behavior that can be observed from an individual community groups and organizations in a specific context is examined from the point of view of the apples, comprehensive and holistic approach. For the purpose of this research, researchers choose to use the type of descriptive research analytically so that the main steps a research which is a description of the research object can be formulated by making it easier for the next step is to do a deep and comprehensive analysis of the object that it is not intended to test the hypothesis, but only describe what it is about the variables, symptoms or the situation and perform the analysis of the facts of the foundation for the guidelines in the future.

The data collected through observation, in-depth interviews, and study of the library. The data is then analyzed used analytical technique or with data processing through the four stages, namely with critical against data, data reduction, classification data and perform the interpretation [5]. While the validity test and reliability of the data is done by the method of triangulation data.

\section{RESULT AND DISCUSSION}

\section{A. Participation and Collaborative Planning of Development in Bandung City}

Collaborative planning is the process of decision making where various stakeholders who see problems from different angles, sitting together to explore their differences to constructively, then seek solutions and to get more from what is obtained if only to find their own solutions. Collaborative planning is based planning communication (rationality communicative). The understanding is obtained from some of the opinion that the collaborative planning is planning that oriented on the stakeholders, involve stakeholders [6] is not limited by the place and time [7].

In practice, collaborative planning could be different implementation, but still contains the principles of authentic dialog, and produce a joint decree. Bertaina et.al, through his research using the eight cases in the Trust Lands of America gives a collaborative planning phase as follows: (1) decide when collaboration implemented, (2) arrange a successful process, (3) determine who will participate, (4) set the process, (5) arrange the structure of the decision-making, (6) help participants work together, (7) share information, and (8) implement the agreement [8].

In the process the regent sitting together in a forum, dialog, and took the decision agreed with as a consensus to be undertaken. This is carried out by the citizens of Bandung especially in one of the government policy of Bandung city named is PIPPK. In this program, which become a target is the host at the level of Rukun Warga (RW) where people will sit together in one forum, dialog and determine the plan of activities will be done.
In planning activities, Awaludin [9] said, communities in RW do consultation for the proposed activities. Consultation is called Rembug Warga which more formal nature. Rembug Warga is a consultation in which the head of RW invited citizens to attend meetings related to the activities that will be proposed to the agency of Bandung city with the date, time, place, and clear target. The proposal directly in the input into an application called e-Musrenbang.

Each RW and LKK has the account of each. For example PIPPK planning in 2018 (planning 2017), RW invited citizens to arrange activities that will be proposed to the agency, and directly inputted at the level of the RW as much as $1584 \mathrm{RW}$ in the city of Bandung. In February in Sabuga, all RW in the city of Bandung collected by the Agency for the socialization was given directly by Ridwan Kamil. Government city of Bandung provide prime card in cooperation with Telkomsel (seluler provider) to access internet e-Musrenbang. So the result of Rembug Warga inserted directly into the application.

In this case the participation of citizens/community is very important. Community participation in the execution of development is one of the conditions in the era of absolute freedom and this openness. Omission of this factors, has been the cause of the deviation which is quite significant for the purpose of development itself is the overall efforts to improve the welfare of the community. Community Participation at the highest level is the community participation that really provide the authority on the community or community. While the participation of the community in the lowest stage is community participation is done just as the process of manipulation or deceives.

Public participation in the process of public policy making according to Smith and Ingram will also provide benefits for the government. Because the government will become more powerful in the sense of no increase institutional capacity in the policy making will be implicated in the improvement of public support for the government, for example voting elections [10]. Other political scientist, was quoted by Glicken [11] said public participation in the decision making process will bring benefits such as contributing to improving the competence of the decision makers through the development of a quality policy-making, provide greater legitimacy to the decisions made for public participation can improve public accountability in the decision making process as well as provide positive image as a democratic society.

\section{B. Collaborative Planning in Innovative Program of Development and Empowerment Territoriality (PIPPK) in Kota Bandung}

PIPPK is Bandung Government program to optimize the task, the role and function of the armed forces and community empowerment city of Bandung is based on tangible symbol. With the spirit of decentralization, innovation and collaboration, various development program will be used in each sub-district. The program initiated since last year this brings positive impact for the development of the city of Bandung, one of these shapes is with achieved the award Adipura. The Mayor of Bandung conveyed that the role of the community in the development of be number one. For this 
reason the concept of PIPPK formed evenly, helpless and together.

The target of PIPPK is the actualization of the commitment and consistency of planning and execution of development activities in Kelurahan is oriented toward the development of the local community and innovation approach, decentralization and collaboration with the needs and ability of the community sub system supported mentoring effective surveillance and control. Now the target of PIPPK is as follows:

a. Improve the ability of society and social institutions in the map the central issues of small-scale development in each Kelurahan;

b. Improve the ability of society and social institutions in Kelurahan to resolve the problems of development in each Kelurahan independently;

c. Improve the ability of the community in the field of community economic development especially the development of entrepreneurship so that open the opportunity to create entrepreneurship the new entrepreneur and new jobs;

d. Strengthen the learning process the management of development in each sub-district.

The principles of the guidance in the implementation of PIPPK is as follows [12]:

a. Hinges on human development, namely the implementation of PIPPK always depends on the improvement of human status and dignity completely;

b. Oriented to the poor, namely all activities conducted through PIPPK prioritise the interests and the needs of the community in general especially poor communities;

c. Innovation is a process that will change the idea of new ideas or modify the idea in development based on community empowerment;

d. The participation through PIPPK, namely the community actively involved in the development process from planning, implementation, control, monitoring and evaluation and reporting including accountability;

e. In the implementation of regional autonomy PIPPK, namely the community has the authority and participative to determine and manage the development of independently;

f. Decentralization through PIPPK, namely the authority of the management of development activities have been transferred to the government tangible symbol and the community in accordance with its capacity;

g. The Equality and gender justice through PIPPK namely, equality role on every stage of the development process and receive the benefits from the results of the development of a fair;

h. Through democratic PIPPK namely, every decision-making the development done by deliberation and compromise with still oriented to the interests of the community; i. Transparency and accountability through PIPPK namely, people have access to all the information and the decision making process so that the management of the activities can be conducted in an open and accountable morally good, technical, legal and administrative privileges;

j. Priorities through PIPPK, namely must prioritize innovation-based development and empowerment by utilizing optimally various potential;

k. Collaboration through PIPPK, namely all stakeholders in the development of pushed to realize and cooperation synergy between stakeholders in the development process;

1. The sustainability through PIPPK, every decision making must consider the interests of improving the welfare of the society in a sustainable and sustainable.

As one of policy's government city of Bandung, effort undertaken by the Government of the city of Bandung is optimize community involvement, especially in the planning of the activities in the RW each. But that does not mean there are problems in planning. According to Awaludin, for planning of the matter is usually in proposing many activities occur duplication, community propose the things that have been proposed in the previous year. This is expected because of the lack of communication between the district and sub-district personnel with the community. Another constraint felt from the side of the monitoring overall, because the problems that duplication new usually realized after activities run. Quite the weight in the conduct of supervision in detail with more funds from 200 Billion and areas that spread in $1500 \mathrm{~s} \mathrm{RW}$.

According to him again, other pain points in the regulation factor, because there is a need to revamp the. There are a number of regulations mayor that should be changed because in the regulation of the community is allowed to use the money to buy the appliance electronics. Even though so many people ask why not buy computer? Explained though allowed but not priority. It is also related to the readiness of the apparatus of the kelurahan, because in kelurahan there are officials who do not have a staff. The budget increase in kelurahan after the PIPPK is $100 \%$. So the existence of the additional burdens for kelurahan but not accompanied with the quality and quantity of the existing apparatus.

The Other obstacle is also associated with a new application e-Musrenbang still quite a lot of human resources in the RW is not yet ready. Whereas previously there is already the socialization may be different understanding. Related to the e-Musrenbang own obstacles that often appear is the proposed activities that less absurd. Some have suggested that the activities of up to 1 Billion because not count down. When it is counted, evidently different very far with ceiling budget. EMusrenbang operates not optimally may be due to the first year.

\section{CONCLUSION}

One of the best practice of collaborative planning in development in the city of Bandung is the existence of innovative program of development and empowerment territoriality (PIPPK). PIPPK is Bandung city Government 
program to optimize the task, the role and function of the armed forces and community empowerment city of Bandung is based on tangible symbol. With the spirit of decentralization, innovation and collaboration, various development program will be used in each sub-district. The program initiated since last year this brings positive impact for the development of the city of Bandung.

In collaborative planning, most important entity is the existence of community participation directly to carry out the rembug bersama arrange or formulate activities, implement and evaluate. PIPPK policy has placed community participation at the highest level where the community really were given authority to plan activities.

PIPPK is innovative activities the Government of the city of Bandung to optimize the task, the role and function of the armed forces and community empowerment city of Bandung is based on tangible symbol. The aim was to make the integrated development can evenly and can be felt by all members of the community.

\section{ACKNOWLEDGMENT}

Thanks to the headship of university and the dean of social and political faculty, Padjadjaran University who has been giving assistance funding so that the opportunity to be able to carry out this research. Also thank you to the team of researchers have conducted research with very good.

\section{REFERENCES}

[1] J.V. Denhardt and R.B. Denhardt, "The New Public Service: Serving, Not Steering", New York: M.E. Sharpe, 2004, pp. 11-12.

[2] N. Haryono, "The Network to Develop Collaboration Public Sector" Jejaring Administrasi Publik. Th.IV (1), 2012, pp. 47-53.

[3] P. Healey, "Collaborative Planning, Shaping Places in Fragmented Societies, 2nd ed" Palgrave Macmillan, New York, 2006; and P. Allmendinger, "Planning Theory", New York: Palgrave, 2002.

[4] "Ridwan Kami Beri Dana Program Rp 100 Juta Tiap RW", retrieved from http://regional.kontan.co.id/news/ridwan-kamil-beri-dana-programrp-100-juta-tiap-rw.

[5] L. Moleong, "Qualitative Research Method" Bandung:Remaja Rosdakarya. 2002, p.32.

[6] M. Tewdwr-Jones, and P. Allmendinger, "Conclusion: Communicative Planning, Collaborative Planning, and the Post-Positivist Planning Theory Landscape", In Tewdwr, 2002.

[7] S. Graham, and P. Healey, "Relational Concepts of Space and Place: Issues for Planning Theory and Practice", European Planning Studies, vol. 7, no. 5, 1999, pp. 623-646.

[8] E. Sufianti, "Leadership and Collaborative Planning to Non-collaboraive Society", Jurnal Perencanaan Wilayah dan Kota. Vol. 25, No. 1, 2014, pp. 78-96.

[9] interview with staff in Sub Sector of Social Cultural and Government Bappelitbang city of Bandung, August 31th, 2017, at $02.00 \mathrm{am}$.

[10] H. Ingran and S.R. Smith, eds, "Public Policy for Democracy, Washington: Brookings, 1993

[11] J. Glicken, "Getting stakeholder participation 'right': a discussion of the participatory processes and possible pitfalls". Environmental Science and Policy, Vol. 3, 2002, pp. 305-310.

[12] Peraturan Walikota Bandung Nomor 436 Tahun 2015 tentang Petunjuk Teknis Pelaksanaan PIPPK, retrieved from https://dlscrib.com/juknispippk-436-2015-doc_589320fd6454a75a07b26bf0_doc.html. 